Львівського УГКЦ на III Міжнародній науковій конференції «Розвиток громадянського суспільства: духовність і право» [Електронний ресурс]. - Режим доступу : http://www.christusimperat.org/uk/node/32899. 9. Смагіна Т. М. Формування громадянської компетентності учнів у процесі навчання правознавства: автореф. дис. на здобуття наук. ступеня канд. пед. наук : спец. 13.00.02 «Теорія та методика навчання»/ Т. М. Смагіна. Київ, 2007. - 15 с. 10. Сопівник I. В. Формування громадянскості студентів вищих аграрних навчальних закладів : автореф. дис. на здобуття наук. ступеня канд. пед. наук : спец. 13.00.07 «Теорія і методика виховання» / I. В. Сопівник. - Тернопіль, - 2006. - 20 с.

\title{
ОСНОВНІ НАПРЯМИ ТА ОСОБЛИВОСТІ ПРОФЕСІЙНОӤ ПІДГОТОВКИ ВЧИТЕЛІВ НІМЕЦЬКОЇ МОВИ В УКРАЇНІ
}

Дзевицька Л. С. Основні напрями та особливості професійної підготовки вчителів німецької мови в Україні.

У статті висвітлено основні напрями та особливості професійної підготовки вчителів німецької мови в Україні. Автор звертає увагу на сутність, форми підготовки майбутніх фахівців з німецької мови в українських педагогічних університетах. Основні принципи системи підготовки вчителів німецької мови розглядаються в розрізі порівняння із західною системою педагогічної підготовки вчителів відповідного профілю.

Ключові слова: іноземна мова, міжкультурна компетенція, освіта протягом усього життя, інноваційні особливості навчально-виховного процесу в школі, університетське співробітництво.

Дзевицкая Л. С. Основные направления и особенности профессиональной подготовки учителей немецкого языка в Украине.

В статье освещены основные направления и особенности профессиональной подготовки учителей немецкого языка в Украине. Автор обращает внимание на сущность, формы подготовки будущих специалистов немецкого языка в украинских педагогических университетах. Основные принципы системы подготовки учителей немецкого языка рассматриваются в разрезе сравнения с западной системой педагогической подготовки учителей соответствующего профиля.

Ключевые слова: иностранный язык, межкультурная компетенция, образование на протяжении всей жизни, инновационные особенности учебно-воспитательного процесса в школе, университетское сотрудничество.

Dzewizka L. S. The main ternds and features of professional training of teachers of German in Ukraine.

The article highlights the main trends and features of professional training of teachers of German in Ukraine. Leading trends, models and methods of professional training of teachers of German at higher educational institutions of Ukraine in the system of education and modern philosophy of the European higher pedagogical education were determined.

The author draws attention to the nature, forms of training of future specialists in German in Ukrainian pedagogical universities, namely the establishment of national standards for teachers of German, reforming continuing education of teachers, improving the professionalism and social status of teachers, improving the competitiveness of educational institutions that train teachers of German language.

Professional competence of teachers of German (professional and business competence, professional-didactic competence, competence of relationships, competence of training, organizational competence, selfcompetence) has aquired a separate consideration, as it is a significant international experience that was used during the standardization and modernization of 
higher pedagogical education in the context of the Bologna process.

Basic principles of training of teachers of German are considered in the context of comparing with the educational system of teacher training in Austria.

Higher School of Education today is in search of the optimal training of future teachers and effective technologies for their education readiness for pedagogical activities. Historically the unique system of training teachers has been developed in every European country, which facets should be investigated to determine the expediency of implementing promising ideas into practice taking into the consideration the features of the country.

The perspective ways of creative use of training of the future teachers of German language schools in Austria and in Ukraine have been determined in this article.

Key words: foreign language, cross-cultural competence, lifelong learning, innovative features of teaching and educational process at school, university cooperation.

Формування інформаційно-технологічного суспільства, докорінні зміни в соціальноекономічному, духовному розвитку держави потребують підготовки вчителя нової генерації. Реалізація цього стратегічного завдання зумовлена також глибинними змінами в системі і структурі загальної середньої освіти та необхідністю інтеграції національної освіти до європейського освітнього простору. Інтеграційні процеси, що відбуваються в умовах європейського освітнього простору, вимагають трансформування національної системи професійної підготовки вчителів середньої школи 3 урахуванням основних принципів Болонського процесу, ключовою позицією якого є якість вищої освіти.

На початку XXI ст. значно посилилися загальні тенденції до демократизації й гуманізації освіти, нового бачення ролі школи, інноваційно-педагогічного розвитку світової педагогічної освіти, зокрема актуальною $є$ тенденція до подолання схеми авторитарного управління педагогічним процесом. Метою розвитку педагогічної освіти в Україні $\epsilon$ створення такої системи професійної підготовки вчителів, яка на основі національних надбань світового значення та усталених європейських традицій забезпечить формування педагогічних кадрів задля здійснення професійної діяльності на демократичних та гуманістичних засадах, реалізацію освітньої політики як пріоритетної функції держави, спрямованої на розвиток та самореалізацію особистості, задоволення ії освітніх і духовнокультурних потреб, а також потреби бути конкурентоспроможними на ринку праці.

Певною мірою вітчизняні і зарубіжні науковці дослідили деякі унікальні й досить продуктивні освітні процеси. Зокрема, розвиток професійної підготовки майбутніх учителів німецької мови в Україні (Н. Гез, О. Глузман, М. Кисельов, Г. Китайгородська, М. Сушон).

Метою статті є аналіз системи вітчизняної професійної системи підготовки майбутніх учителів німецької мови, їі особливостей та основних напрямів.

Освіта належить до найважливіших напрямів державної політики України. Держава виходить 3 того, що освіта - це стратегічний ресурс соціально-економічного, культурного й духовного розвитку суспільства, поліпшення добробуту людей, забезпечення національних інтересів, зміцнення міжнародного авторитету й формування позитивного іміджу нашої держави, створення умов задля самореалізації кожної особистості.

Якісна освіта $\epsilon$ важливою умовою забезпечення сталого демократичного розвитку українського суспільства, консолідації всіх його інституцій, гуманізації суспільноекономічних відносин, формування нових життєвих орієнтирів особистості [6]. Проблема реформування освіти є досить актуальною і знаходиться на першому місці у вітчизняній освітній системі. Потреба в модернізації та вдосконаленні знань та умінь існуватиме завжди, a накопичення досвіду i знань видається як закономірність, оскільки нове покоління характеризувалося винаходами, застосуванням передових технологій та розвитком науки. Розуміння того, що необхідно зберігати баланс між консерватизмом та інноваційністю, у світі повинно стати загальним принципом освітньої політики кожної держави.

Саме тому педагогічна наука сьогодення характеризується безперервним пошуком нових методів та форм навчання. Метою пошуку є не тільки збагачення гуманітарної науки, 
a й розв'язання проблем у галузі педагогіки сьогодення та можливе їх майбутнє передбачення [8]. Українська педагогічна думка перебуває під впливом постіндустріального та постінформаційного суспільства, тому багато науковців шукають саме шляхи оптимізації освіти в умовах потреб і запитів держави.

Історію методики досліджували Н. Гез [1], Г. Китайгородська [5], А. Утробіна [10] й інші науковці. Класифікація методів навчання іноземних мов $є$ складним питанням, тому що в основу їхнього найменування покладено достатньо різні ознаки. Залежно від того, який аспект превалює у викладанні, метод називається лексичним або граматичним; залежно від того, які логічні категорії $є$ основними, - синтетичним або аналітичним. Відповідно до того, розвиток якого вміння є метою навчання, розрізняють усний метод і метод читання. За способом семантизації матеріалу - перекладний і прямий методи. Назва методу визначається прийомом, покладеним в основу роботи над мовою, наприклад, аудіовізуальний, наочний. За принципом організації матеріалу традиційному методу протиставляють метод програмованого навчання.

Іноземна мова розширює лінгвістичний світогляд та сприяє формуванню культури спілкування. Підготовка в педагогічному університеті націлює майбутніх викладачів німецької мови, передовсім, на досягнення учнями подальших цілей та вироблення відповідних компетенцій: подальший розвиток іноземної комунікативної компетенції, мовна компетенція, соціокультурна компетенція, компенсаторна компетенція, навчальнопізнавальна компетенція, розвиток та виховання.

Підготовка майбутнього вчителя німецької мови в Україні заснована на принципі набуття студентами таких навичок: розуміння культурної специфіки загальної людської поведінки; розуміння системи орієнтації, яка є характерною для рідної культури; розуміння значення культурних чинників у процесі комунікативної взаємодії. На заняттях порівнюється українська культура 3 культурою німецькомовних країн, виокремлюються й дискутуються спільні та відмінні риси обох культур.

На противагу українській, західна система освіти базується на цінностях лібералізму. Розвиток та вдосконалення західної педагогічної думки відбувалися упродовж кількох етапів і спроб. Водночас на сучасному етапі майбутнім учителям в університетах ретранслюють знання щодо первинності і вартістності людини, розуміння того, що держава існує для людей і через людей, а не постає над людьми і поза людьми. Отже, західноєвропейська педагогічна думка багато в чому перевершує вітчизняну.

На нашу думку, особливість професії вчителя німецької мови полягає в тому, що фахівець перебуває в епіцентрі різних виявів культури, а його робота знаходиться на стику найрізноманітніших знань, адже йому необхідно крім самої мови, знати величезну кількість речей і явищ, які зазвичай обговорюються на уроках німецької мови. Вивчення німецької мови складається 3 двох основних напрямків: навчання правил (загальне) і засвоєння лексики, виразів, ідіом (конкретне). Практично неможливо вивчити структуру мови «взагалі», оскільки по суті це завжди виявляється структура, застосована до конкретних тем, на які ми говоримо, про які пишемо або читаємо. Тому майбутній учитель німецької мови повинен розбиратися в історії, географії, політиці, соціології, психології, бізнесі, подорожах, спорті, медицині, музиці, кіно, літературі, мистецтві задля того, щоб навчати своїх учнів спілкуватися на необхідні їм у житті і професійній діяльності теми, кількість яких достатня.

Аналіз сучасної освітньої ситуації показує необхідність міжкультурної орієнтації, оскільки саме вона $є$ необхідним чинником освітньої інтеграції до загальноєвропейського простору. По суті міжкультурна компетенція майбутнього вчителя німецької мови - це основа для формування національної самосвідомості, для розвитку вміння бачити власну національну перспективу, що безпосередньо співвідноситься 3 цілями навчання в педагогічному університеті, оскільки набуває на сьогодні вагомого виховного значення [4].

У зв'язку з цим рідна мова й рідна культура, так само як і актуальна сучасна дійсність, стають зрозумілими компонентами в практичній підготовці вчителів німецької мови в українських педагогічних університетах. Їх співвідношення з основними аспектами навчання 
німецької мови як іноземної потребує теоретичного осмислення та вимагає серйозного аналізу з точки зору можливих шляхів реалізації й упровадження в навчальний процес.

Для формування міжкультурної компетенції в рамках чинних програм доцільно переглянути традиційний розподіл змістових компонентів професійної підготовки вчителя німецької мови, який стосується, передовсім, співвідношення лінгвістичних, літературознавчих, культурологічних аспектів у германістичній освіті, формально не представленим у «класичному» доборі дисциплін навчальних планів. Це, у свою чергу, допоможе здійснити якісні модифікації і засоби розвитку, формування навичок вираження думок як рідною, так і іноземною (німецькою) мовою, оскільки «основною справою літературознавства й лінгвістики є формування єдиного мовного образу студента» [11].

Для того щоб здійснити вище зазначені цілі, необхідно опанувати нові технології в навчанні німецької мови та підготувати нові навчально-дидактичні комплекси, навчальні матеріали нового покоління, які будуть відповідати двом вимогам: брати до уваги міжкультурну перспективу й кардинально покращувати якість розуміння навчального матеріалу [3].

Відомо, що в Україні проводяться різноманітні конференції та круглі столи, під час яких обговорюються сучасні проблеми педагогіки та презентуються iï новітні досягнення. Роль іноземної мови в забезпеченні якісної освіти досить висока. Порушуються питання використання IКТ не тільки на уроках, а й у процесі підготовки та перепідготовки вчителів, організації навчання через дистанційну форму навчання, проведення вебінарів для вчителів, створення не тільки посібників, а й навчально-методичних комплектів.

Не слід забувати, що в загальноєвропейських компетенціях володіння іноземною мовою виокремлені певні рівні, які розглядають як складники поняття комунікативної компетенції майбутніх учителів німецької мови. Ці три рівні: А - елементарні знання (А 1рівень виживання, А 2 - передпороговий), В -самостійне володіння (В 1- пороговий рівень, В 2 - пороговий просунутий рівень), С- вільне володіння (С 1- рівень професійного володіння, С 2 - досконалий рівень).

Звичайно, майбутньому вчителю німецької мови важливо володіти своїм предметом на досконалому рівні, але, тим не менш, найголовніше для нього - це не стільки знання мови, скільки вміння ії викладати. Вчитель німецької мови повинен володіти широким світоглядом і знати культуру тієї країни, мову якої він викладає.

Слід зазначити, що в Україні активно реалізуються всесвітні та міждержавні проекти, метою яких є інтенсифікація та поглиблення вивчення німецької мови. Наприклад, з 8 липня 2013 року 3 ініціативи Гете-Інституту (німецька громадська організація, метою якої $\epsilon$ популяризація німецької мови за кордоном та підтримка міжнародної культурної співпраці різних країн з Німеччиною) в Україні, за сприяння Департаменту освіти Донецької облдержадміністрації на базі Донецького обласного інституту післядипломної педагогічної освіти розпочала роботу регіональна літня школа мовного інтенсивну для вчителів загальноосвітніх шкіл, які викладають німецьку мову як першу або другу іноземну [7].

Перехід до нових стандартів навчання, зокрема нового стандарту мовної освіти в Україні, передбачає створення плюрилінгвального простору за рахунок вивчення другої іноземної мови, мов національних меншин, розширення обсягу міжкультурного спілкування. Саме тому задля популяризації й підтримки німецької мови в Україні Гете-Інститут розробив цей проект. Важливо також, що на базі Гете-Інституту студенти та викладачі німецької мови можуть здавати різноманітні іспити на підтвердження рівня знань з німецької мови. Інститут розробив систему кваліфікаційних іспитів для тих, хто вивчає німецьку мову як іноземну (Deutsch als Fremdsprache, DaF) для рівнів від А 1 до C 2. Ці іспити, що відповідають стандарту Загальноєвропейських компетенцій володіння іноземною мовою, можна складати як у Німеччині, так і за ії межами, зокрема і в Україні. Окрім цього, працює проект «Великий диплом з німецької мови» («Großes Deutsches Sprachdiplom») для тих, хто володіє мовою на більш просунутому рівні.

Сучасна педагогіка виносить на передній план таке поняття, як «лінгводидактична 
культура» вчителя іноземної мови. Під терміном «лінгводидактична культура» майбутнього вчителя німецької мови мається на увазі одна із найважливіших характеристик професійної культури вчителя як цілісної системи взаємопов'язаних психолого-педагогічних, лінгвістичних, лінгвістично-методичних, дидактичних знань та вмінь, які передбачають наявність комунікативних, організаторських і творчих здібностей, а також такі професійно значущі якості, як самоконтроль, емпатія, рефлексія у процесі педагогічної діяльності.

Однією з тенденцій розвитку сучасного суспільства $є$ перехід до освіти протягом життя. Це питання $є$ також актуальним в українській педагогічній системі, оскільки суспільству, яке розвивається, вкрай необхідні кваліфіковані спеціалісти, різнобічно освічені люди, які можуть самостійно приймати відповідальні рішення в ситуації вибору, прогнозуючи їх наслідки, готові до співпраці, гнучкі, динамічні, комунікативні та відповідальні співробітники. Підвищення професійного рівня $\epsilon$ необхідною умовою модернізації системи освіти України. У сучасних умовах вчителі повинні швидко та без перешкод оволодівати новими способами діяльності, успішно виконуючи при цьому обов'язки.

Багато в чому підготовка майбутніх учителів німецької мови в українських педагогічних університетах залишається традиційною і майже позбавленою інноваційних змін сучасного суспільного розвитку. Вітчизняна педагогічна освіта $\epsilon$ недостатньо професійно-спрямованою, науково-обгрунтованою, характерним $є$ також істотний розрив між теорією та практикою, незважаючи на те, що практика в школі триває довше, ніж в австрійських педагогічних університетах. На жаль, відсутня рефлексія теоретичних знань та їх аплікація в пошуковій студентській діяльності, а згодом і в практичній роботі вчителя [9].

Навчання в університеті передбачає ознайомлення майбутніх учителів німецької мови із інноваційними особливостями навчально-виховного процесу в школі, наприклад:

- гуманізація процесу навчання німецької мови, що передбачає посилення уваги до особистості кожного учня як вищої соціальної цінності суспільства, установку на формування громадянина 3 високими інтелектуальними, моральними та фізичними якостями;

- альтернативні навчально-методичні комплекти;

- культурологічний підхід до відбору та методичної організації змісту навчання німецької мови;

- краще усвідомлення вітчизняної культури через посилення ролі німецької мови у вихованні учнів і залучення їх до світової культури;

- ранній початок вивчення (дошкільниками) німецької мови;

- профільно-орієнтоване навчання старшокласників німецької мови;

- використання елементів проблемного та інтенсивного навчання німецької мови;

- використання таких сучасних технологій навчання, як проектна методика, навчання у співпраці тощо;

- система застосування лінгводидактичного тестування учнів.

Поява загальноєвропейських рекомендацій із мовної освіти - вивчення, викладання, оцінювання, які мають бути старанно вивчені вчителями, бо саме в них можна знайти багато відповідей на питання сучасної освіти взагалі та української зокрема [2].

Нині перед вищою педагогічною школою стоїть задача вдосконалення змісту і методів навчання майбутніх учителів німецької мови для середньої школи, підвищення ефективності навчально-виховного процесу в університеті. У сучасних умовах не тільки значно зростає роль вищої педагогічної школи, але й змінюються іiі функції: навчальні заклади займаються не тільки підготовкою вчителів, але й стають своєрідними науковими i навчальними центрами з перепідготовки і підвищення кваліфікації працюючих учителів.

У зв'язку 3 цим особливого значення набуває співробітництво педагогічних університетів із школами та органами освіти. На межі століть Європа кардинально змінює своє ставлення до педагогічної освіти - однієї з найбільш соціальних галузей, що об'єднує значну кількість студентів - майбутніх учителів, працюючих учителів, соціальних 
працівників. Отже, використовуючи досвід австрійських педагогічних університетів, українські вищі педагогічні школи мають зміцнювати контакти між педагогічним університетом і школою. Це робиться задля з'ясування реальної ситуації в середніх школах та ретрансляції цих знань майбутнім учителям. Педагогічна освіта сучасності повинна займатися актуальними питаннями.

Незмінним залишається той факт, що вивчення будь-якої іноземної мови - це більше, ніж оволодіння іï граматичною, лексичною чи фонетичною системами. Учитель іноземної мови, як жодний інший, є тим посередником, який створює зв'язок засобами мови між народами та культурами. Професійна компетенція майбутнього вчителя німецької мови формується у процесі розвитку і саморозвитку особистості педагога. Викладачі, які володіють професійними компетенціями, є компетентними спеціалістами у своїй справі, а також відповідають вимогам сучасності і є достатньо конкуретноздатними на ринку праці.

Отже, однією із важливих та актуальних проблем на сучасному в Україні є якісна професійна підготовка вчителів середньої школи, зокрема і майбутніх учителів німецької мови, яка допоки не відповідає оновленим вимогам суспільства та не забезпечує достатнього рівня розвитку педагогічної компетентності. Важливою проблемою залишається пошук ефективних шляхів, забезпечення потрібних і достатніх умов задля вдосконалення процесу професійної підготовки вчителів-професіоналів, здатних до творчої організації всіх ланок особистісно зорієнтованого педагогічного процесу, до самореалізації, до виконання нового соціального замовлення. Доведено, що в умовах глобальної модернізації освіти важливо визначити підходи до аналізу системи професійної підготовки вчителів за кордоном, зокрема в Австрії, з тим, щоб надалі обгрунтовано оцінити доцільність перенесення накопиченого позитивного досвіду в систему освіти України. Безумовно, українська система професійної підготовки вчителів є вагомим складником світової системи освіти, могутнім фактором розвитку продуктивних сил суспільства й духовної культури народу, тому іiі наукове пізнання вимагає системного підходу, а вдосконалення неможливе без порівняльного аналізу з особливостями професійної підготовки вчителів в інших країнах світу.

\section{Література}

1. Гез Н. И. История зарубежной методики преподавания иностранных языков / Н. И. Гез, Г. М. Фролова. - Москва : Академия, 2008. - 256 с. 2. Глузман А. В. Профессионально-педагогическая подготовка студентов университета: теория и опыт исследования : [монография] / А. В. Глузман.- Київ : Поисково-издательское агентство, 1998. - 252 с. З. Захарченко Е. Ю. Педагогическая культура и культурно-образовательная ситуация / Е. Ю. Захарченко // Педагогика. - 1999. - № 3. - С. 69-73. 4. Кисельов М. Феномен гуманітарної освіти в Україні / М. Кисельов // Освіта і управління. - 1997. - Т. 1. № 1. - С. 129-133. 5. Китайгородская Г. А. Методика интенсивного обучения иностранным языкам / Г. А. Китайгородская. - Москва : Высшая школа, 1986. - 112 с. 6. Комарницька Т. М. Кваліфікаційна характеристика вчителя іноземної мови в контексті сучасних наукових, психолого-педагогічних теорій, методів та технологій навчання [Електронний ресурс] / Т. М. Комарницька ; Чорноморський держ. ун-т ім. Петра Могили. Режим доступу : http://lib.chdu.edu.ua/index.php?m=23\&b=7 7. Концептуальні засади розвитку педагогічної освіти України та іiі інтеграції в європейський освітній простір [Електронний pecypc] : наказ МОН № 988 від 31.12.04 року. - Режим доступу : http://osvita.ua/legislation/ Vishya_osvita/3145/ 8. Лукин Г. И. Становление и развитие государственных инновационных образовательных учреждений / Г. И. Лукин // Менеджмент в образовании. - 2004. - №1. С. 48-55. 9. Сушон М. Образование и средства массовой информации : точки соприкосновения и проблемы / М. Сушон // Перспективы. Вопросы образования. -1982. №1. - С. 146-158. 10. Утробина А. Методика преподавания и изучения иностранного языка / А. Утробина. - Москва : Приор, 2006. - 112 с. 11. Щепкина Е. Опыт историкосоциологического анализа мотивации студентов/ Е. Щепкина // Высшее образование в России. - 1997. - С. 68-77. 